\title{
Student Learning Motivation: Perceptions of Teaching Methods and Learning Media
}

\author{
Sri Mulyati ${ }^{1, *}$ Meta Arief ${ }^{2}$ Rasto $^{3}$ \\ ${ }^{1,2,3}$ Universitas Pendidikan Indonesia \\ *Corresponding author. Email: srimulyati@upi.edu
}

\begin{abstract}
The purpose of this study is to identify the effect of student perceptions of teachers' teaching methods and the use of instructional media on student accounting learning motivation. 139 people were involved as the respondents of the study. Then, the explanatory survey method was used as the research method. The results showed that there was a positive and significant effect of the teachers' teaching methods on student accounting learning motivation. Then, there was a positive and significant effect of the use of instructional media on student accounting learning motivation. Additionally, there was a positive and significant effect of the teachers' teaching methods and the use of learning media both partially and simultaneously on student accounting learning motivation. Through the score trend categorization of the good category, the results of teachers' teaching methods are higher than the results of the use of instructional media.
\end{abstract}

Keywords: Teachers' Teaching Methods, Learning Media, Accounting Learning Motivation

\section{INTRODUCTION}

Learning is defined as the processes of interaction among teachers, students, and learning resources in the learning environment $[1,2,3,5]$. The learning processes carried out in the classroom are determined by several learning components covering: learning objectives, teaching materials, methods and media, evaluation, students, and teachers $[4,5]$. The field of accounting study in vocational high schools has certain competencies in accordance with the characteristics of vocational education. There are three characteristics of vocational education out of the sixteen theories consisting of: (1) vocational education is targeted at preparing students for employment, (2) the focus of vocational education contents is emphasized on assigning knowledge, skills, attitudes, and values required in the workplaces, and (3) good vocational education is responsive and anticipatory towards the advancement of technology [6].

The 2013 curriculum emphasizes the character-based and competency-based education [7]. In general, character education puts more concern on exemplary, creating an environment, and habit; through various scientific tasks and conducive activities [8]. The creation of a conducive environment can be done through a variety of methods covering: assignments, habituation, training, learnings, directions, and examples [7, 8]. There are several learning methods that can be applied by teachers including: lecture, demonstration, discussion, and simulation methods $[9,10,11]$. In addition, there are other methods, such as the question and answer, learning and recitation task, group work, demonstration and experimental, group system, and training, challenging questioning, and self-evaluation methods $[12,13]$. Another means of learning is the utilization of information technology in the learning [50] processes. As an integral part, learning media is regarded a part of the learning strategies. The utilization of learning media in the teaching and learning process can encourage new desires and interests, motivation and stimulation of learning activities, and even bring psychological influences on students [4, 14]. Learning media are divided into four groups covering: printed media, audiovisual media, computer-based media, and combined media between printed and computer technology [15].

The study conducted by Khasanah and Istiningrum [16] on students' perceptions of the variations in teachers' teaching methods on accounting learning motivation showed that there was a positive effect on students' perceptions of variations in teachers' teaching methods on student learning motivation. Similarly, the study conducted by Suhendra, et al. [17] on the effect of using audiovisual learning media on student learning motivation [2] showed that there was a positive effect of the use of instructional media on student learning motivation. In addition, the study conducted by Saputri, et al. [18] regarding the Prezi media presentations in the Accounting subject showed that it indeed enhanced and 
had a positive effect on student accounting learning motivation. Based on the aforementioned elaboration, the hypothesis of this study is that the variation of teachers' teaching methods and learning media has a positive effect on student accounting motivation [2].

\section{LITERATURE REVIEW}

\subsection{Teachers' Teaching Methods}

Teaching methods are the methods used by teachers to implement learning plans or strategies that have been prepared in the real activities in order to achieve the set objectives optimally $[9,19,20]$. In addition, some stated that teaching methods are defined as methods used by teachers to deliver learning materials and establish relationships between teachers and students during the teaching learning processes $[12,21]$. Therefore, it can be concluded that methods play an important role in teaching: 1) Methods are viewed as a tool for extrinsic motivation. One of the teaching components that can provide learning motivation to students is teachers. The ability of teachers in applying a variety of teaching methods can arouse and maintain student learning motivation. The teaching method used by the teacher must promote positive attitudes of students and arouse passion and enthusiasm for learning. 2) Methods are regarded as a teaching strategy. In principle, teaching strategies are the real action of a teacher in teaching by using certain methods and using teaching components (goals, materials, methods, tools, and evaluation) that aim to achieve the set learning objectives for students. One of the methods used to properly implement a strategy is to use various teaching methods. 3) Methods are seen as a tool in order to achieve objectives. The purpose of teaching will not be achieved if one component of teaching is not involved. One of these components is the teaching method. Through these teaching methods, teachers can connect students with materials and learning resources. Through methods, students can master the teaching materials as the objectives of teaching [22].

\subsection{Learning Media}

Learning media are defined as everything that can be used to disseminate messages and stimulate thoughts, feelings, attention, and desires of students so that they can actively involve in the teaching and learning process [23] [24]. In addition, media is also [15] regarded as a technique used to make communication more effective between teachers and students in the process of education and learning [12] on the basis of needs, contents, objectives, and teaching methods $[25,26]$. In particular, the process of teaching and learning is also viewed as a communication process [12] in which there are reciprocity between teachers and students [27]. In principle, communication will not work without the means of delivering messages or media. Therefore, in the teaching and learning process, learning media are highly needed to facilitate the delivery of materials.

The practical benefits of using instructional media in the teaching and learning process are as follows: (1) learning media can be the means of clarifying the presentation of messages and information so that it can help facilitate learning processes and outcomes, (2) learning media can increase and direct the student attention so that it can lead to learning motivation [9] , (3) learning media can overcome sensory, space, and time [5] limitations, (4) learning media can provide [5] students with similar experiences about events in their environment $[28,29]$. The use of learning media in the teaching and learning process can generate new desires and interests, generate motivation and stimulation of learning activities, and even bring psychological effects on students $[4,30]$.

\subsection{Motivation}

Motivation is defined as a psychological process that provides purposes and directions of behavior or intentional behavior to achieve specific unfulfilled needs [31]. In addition, it is also regarded as a change in energy in a person characterized by the emergence of "feeling" and preceded by a response to the existence of objectives [27]. Operationally, motivation is defined as an inner strength that encourages individuals to achieve personal and organizational goals [14, 31].

\subsection{Student Learning Motivation}

Motivation and learning is considered as the two inter-influential things. In principle, motivation can help understand and explain individual behavior, including student behavior [32].

\subsection{Hypothesis}

$H_{1}=$ teaching methods of teachers' methods have a positive effect on learning motivation [2].

$\mathrm{H}_{2}$ = learning media have a positive effect on learning motivation [2].

$\mathrm{H}_{3}$ = teaching methods of teachers and learning media have a positive effect on learning motivation [2].

\section{METHODS}

Based on the characteristics of the set research problems, this present study was classified into a comparative causal study [5]. This study was conducted in order to identify the effects of independent variables on the dependent ones. Based on the applied method, this study was considered as an ex-post-facto study. In addition, a quantitative approach was also employed in this present study. In fact, the data of this study were in the form of numbers and the data were analyzed statistically. The explanatory survey method was also 
employed as the research method. In other words, it used the research instruments in the form of questionnaires as a means of collecting data from the sample population in order to explain the effects of teaching methods of teachers and the use of learning media on learning motivation. This study revealed the existing data and was not subject to certain treatments for the research variables [2]. In this study, the dependent variable was the accounting learning motivation marked with $\mathrm{Y}$, the independent variable was the teacher's teaching method marked with $\mathrm{X}-1$, and the use of instructional media was marked with X-2. The population of this study was 139 students consisting of $3610^{\text {th }}$ Grade Accounting 1 students, $3510^{\text {th }}$ Grade Accounting 2 students, $3310^{\text {th }}$ Grade Accounting 3 students, and $3510^{\text {th }}$ Grade Accounting 4 students. The Slovin formula was employed as the method to determine the number of samples. The expected reliability of the samples was $95 \%$ or the error rate of $5 \%$. Therefore, the number of the samples was 103 students. In this study, the proportional

Table 1. Trend Categorization of Teachers' Teaching Method Variable Scores

\begin{tabular}{|c|c|c|c|c|}
\hline No & Score Range & Total & Frequency (\%) & Categories \\
\hline 1 & $>45$ & 67 & 51,07913669 & Good \\
\hline 2 & $30-45$ & 71 & 48,20143885 & Fairly Good \\
\hline 3 & $<30$ & 1 & 0,71942446 & Poor \\
\hline & Total & 139 & 100 & Fairly Good \\
\hline
\end{tabular}

Table 1 shows that there are 52 (37.4) respondents who have perceptions of teacher teaching methods in the good category, $85(61.15 \%)$ respondents in the fairly good category, and $2(1.4 \%)$ respondents in the poor category. The results of the use of learning media are measured through the following 5 indicators: 1) media suitability with learning objectives, 2) media suitability random sampling was also used as the sampling technique. The detail numbers of samples were presented as follows: $2610^{\text {th }}$ Grade Accounting 1 students, $2610^{\text {th }}$ Grade Accounting 2 students, $2710^{\text {th }}$ Grade Accounting 3 students, and $2410^{\text {th }}$ Grade Accounting 4 students.

\section{RESULTS AND DISCUSSION}

The results of the teachers' teaching method are measured through the following 5 indicators: 1) the suitability of the method with the students, 2) the suitability of the method with the objectives, 3) the suitability of the method with the situations, 4) the suitability of the method with the facilities, and 5) the suitability of the method with the teacher's competency. The following table is the percentage of the frequency of categorizing the trends of teachers' teaching method variable scores.

Table 2. Trend Categorization of The Use of Learning Media Variable Scores

\begin{tabular}{|c|c|c|c|c|}
\hline No & Score Range & Total & Frequency (\%) & Categories \\
\hline 1 & $>45$ & 40 & 28,77697842 & Good \\
\hline 2 & $30-45$ & 96 & 69,0647482 & Fairly Good \\
\hline 3 & $<30$ & 3 & 2,158273381 & Poor \\
\hline & Total & 139 & 100 & Fairly Good \\
\hline
\end{tabular}

The table shows that there are 40 (28.77\%) respondents who have a perception of the use of instructional media in the good category, $96(69.06 \%)$ respondents are in the fairly good category, and 3 $(2.15 \%)$ respondents are in the poor category. Afterward, the results of the motivation are measured through the following 8 indicators: 1) perseverance, 2) tenacity, 3) with materials, 3) media suitability with student characteristics, 4) media suitability with learning styles and student interests, and 5) media suitability with environmental conditions, supporting facilities, and available time. The following is the percentage of the frequency of categorizing the trend of the use of learning media variable scores. learning interest, 4) independence, 5) being happy to solve problems, 6) getting bored quickly on routine tasks, 7) being able to maintain opinions, 8) not easily sacrificing their beliefs. The following Table 3 shows the percentage of the frequency of categorizing the trends of the student motivation variable scores. 
Table 3. Trend Categorization Of Student Learning Motivation Variable Scores

\begin{tabular}{|c|c|c|c|c|}
\hline No & Score Range & Total & Frequency (\%) & Categories \\
\hline 1 & $>48$ & 22 & 15,82733813 & High \\
\hline 2 & $32-48$ & 113 & 81,29496403 & Medium \\
\hline 3 & $<32$ & 4 & 2,877697842 & Low \\
\hline & Total & 139 & 100 & Medium \\
\hline
\end{tabular}

Table 3 indicates that $22(15.8 \%)$ respondents have the accounting learning motivation in the high category, $113(81.29 \%)$ respondents have the accounting learning motivation in the medium category, and $4(2.87 \%)$ respondents have the accounting learning motivation in the low category. Furthermore, the results of data analysis are displayed using multiple linear regression by the help of the SPSS Statistics 25 application for Windows. The summary of the test results is presented in the following Table 4.

Table 4. Multiple Regression Coefficient Model

\begin{tabular}{|c|c|c|c|c|c|c|c|}
\hline \multirow[t]{2}{*}{ Model } & \multicolumn{2}{|c|}{$\begin{array}{l}\text { Unstandardized } \\
\text { Coefficients }\end{array}$} & \multirow{2}{*}{$\begin{array}{c}\text { Standardized } \\
\text { Coefficient } \\
\text { Beta }\end{array}$} & \multirow[t]{2}{*}{$\mathrm{t}$} & \multirow[t]{2}{*}{ Sig. } & \multicolumn{2}{|c|}{ Collinearity Statistics } \\
\hline & B & Std. Error & & & & Tolerance & VIF \\
\hline (Constant) & 22,492 & 3,589 & & 6,267 &, $000 b$ & & \\
\hline $\begin{array}{l}\text { Teaching } \\
\text { method }\end{array}$ & ,240 & ,081 &, 270 & 2,978 & ,003 &, 724 & 1,381 \\
\hline Learning media & , 218 & ,086 & ,231 & 2,551 &, 012 & ,724 & 1,381 \\
\hline
\end{tabular}

Based on table 4 above, the multiple linear regression equation can be stated as follows:

$$
\begin{aligned}
& Y=a+b X 1+b X 2 \\
& Y=22,492+0,270 X 1+0,231 X 2
\end{aligned}
$$

In the equation, there is a constant of 22,492 which implies that if there is no change from the variable of teachers' teaching method and the learning media, then the level of student learning motivation level is 22,492 . The coefficient X1 of teachers' teaching method is 0.270 and it implies that if the teacher's teaching method (X1) increases one unit so the value of accounting learning motivation (Y) will increase by 0.270 units. X2 coefficient of learning media usage is 0.231 , which means that if the use of learning media (X2) increases by one unit then the value of accounting learning motivation (Y) will increase by 0.231 units.

The further phase is to test the hypothesis. To do a hypothesis test, an ANOVA table is used for the F-test and a coefficient table is used for the t-test. The following Table 5 is used to portray the steps for testing hypotheses:

\begin{tabular}{|c|c|c|c|c|c|}
\hline Model & $\begin{array}{l}\text { Sum of } \\
\text { Squares }\end{array}$ & df & $\begin{array}{l}\text { Mean } \\
\text { Square }\end{array}$ & $F$ & Sig. \\
\hline $\begin{array}{l}1 \\
\text { Regressio } \\
n\end{array}$ & 769,795 & 2 & 384,897 & 16,130 &, $000 \mathrm{~b}$ \\
\hline $\begin{array}{ll} & \text { R } \\
\text { esidual } & \end{array}$ & 3245,357 & 136 & 23,863 & & \\
\hline otal & 4015,151 & 138 & & & \\
\hline
\end{tabular}

Table 5. Analysis of Variance

a. Predictors: (Constant), Learning media, Teaching method

b. Dependent Variable: Learning motivation

Table 5 ANOVA above is used to test the positive effect of students' perceptions of teachers' teaching methods and the use of instructional media on accounting learning motivation in the entire Vocational High Schools, Bandung. The hypothesis of this study can be seen as follows:

$\mathrm{H} 0: \mathrm{R}=0$, the teachers' teaching methods and the use of instructional media do not have a positive effect on accounting learning motivation. 
$\mathrm{H} 1: \mathrm{R} \neq 0$, the teachers' teaching methods and the use of instructional media have a positive effect on accounting learning motivation.

If $\alpha<0,05$, then $\mathrm{H} 0$ is rejected and $\mathrm{H} 1$ is accepted

If $\alpha<0,05$, then $\mathrm{H} 0$ is accepted and $\mathrm{H} 1$ is rejected

Based on Table 5 above, the multiple regression tests are carried out with the F-test. The results showed that the value of $\mathrm{F}$ count is 16,130 with the significance of $0,000<0,005$. If it is compared with the value of $F$ table Table 6. Coefficient Determination

\begin{tabular}{|l|l|l|l|l|l|}
\hline \multicolumn{1}{|c|}{ Model } & \multicolumn{1}{|c|}{$\mathrm{R}$} & \multicolumn{1}{|c|}{ R Square } & \multicolumn{1}{|c|}{ Adjusted R Square } & \multicolumn{1}{c|}{$\begin{array}{c}\text { Std. Error of the } \\
\text { Estimate }\end{array}$} & Durbin-Watson \\
\hline 1 & 1438 & 192 &, 180 & 4,885 & 2,132 \\
\hline
\end{tabular}

c. Predictors: (Constant), Learning media, Teaching method

d. Dependent Variable: Learning motivation

e.

Based on Table 6, it is obvious that the large contribution of the effective effect of each independent variable on the magnitude of accounting learning motivation is $19.2 \%$ for teacher teaching method variables and the use of learning media, while the remaining $80.8 \%$ is influenced by other factors not examined. Therefore, it can be concluded that: 1) there is a positive and significant effect of teachers' teaching methods on student accounting learning motivation. 2) there is a positive and significant effect of the use of instructional media on student accounting learning motivation, 3) there is a positive and significant effect of teachers' teaching methods and the use of instructional media both partially and stimulative on student accounting learning motivation. Therefore, teachers' teaching methods and the use of instructional media collectively should be paid attention in order to increase student accounting learning motivation. The better the students 'perceptions of teachers' teaching methods and the use of learning media are, the higher the student accounting learning motivation is.

\section{CONCLUSION}

Accounting learning in vocational school requires specific learning process and competencies of the education. aiming to identify how students perceive the teaching methods and the use of instructional media on how it motivates them, this study observes the teaching and learning process in the Accounting Class Grade 1-4. The results showed that there was a positive and significant effect of the teachers' teaching methods on student accounting learning motivation. Then, there was a positive and significant effect of the use of instructional media on student accounting learning motivation. Additionally, there was a positive and significant effect of the teachers' teaching methods and the use of learning at the significance level of $5 \%$ of 3.12 , the value of the $\mathrm{F}$ count is $>\mathrm{F}$ table ( $\mathrm{F}$ count $>\mathrm{F}$ table). Therefore, it is clear that there is a positive and significant effect of teachers' teaching methods and the use of instructional media collectively on the Accounting learning motivation of the 10th Grade Accounting students in Bandung City. The magnitude of the effects of the teachers' teaching methods and the use of instructional media variables on student accounting learning motivation can be seen through the following Table 6 .

media both partially and simultaneously on student accounting learning motivation. Through the score trend categorization of the good category, the results of teachers' teaching methods are higher than the results of the use of instructional media.

\section{REFERENCES}

[1] M. I. Pambudi, M. E. Winarno, W. D. Dwiyogo. Perencanaan dan Pelaksanaan Pembelajaran Pendidikan Jasmani Olahraga Kesehatan. Jurnal Pendidikan: Teori, Penelitian, dan Pengembangan, Malang: Universitas Negeri Malang, vol. 4 (1), 2019, pp. 110-116.

[2] B. Badelah, M. Mahsun, B. Burhanuddin, Tindak Tutur Kesantunan Guru dan Siswa dalam Pembelajaran Bahasa Indonesia di SMP Negeri 2 Sakra: Tinjauan Pragmatik, LINGUA: Jurnal Bahasa, Sastra, dan Pengajarannya, Surakarta: Pusat Kajian Bahasa dan Budaya, vol. 16 (2), 2019, pp. 219-234.

[3] V. L. P. Sutrisno, B. T. Siswanto. Faktor-faktor yang mempengaruhi hasil belajar siswa pada pembelajaran praktik kelistrikan otomotif SMK di Kota Yogyakarta. Jurnal Pendidikan Vokasi, Yogyakarta: Universitas Yogyakarta, vol. 6 (1), 2016, pp. 111-120.

[4] A. Pane,M. D. Dasopang, Belajar dan pembelajaran, Fitrah: Jurnal Kajian Ilmu-ilmu Keislaman, Padang Sidempuan: IAIN Padang Sidempuan, vol. 3 (2), 2017, pp. 333-352.

[5] R. Elvi, Perbedaan Individual Mahasiswa dalam Mata Kuliah Pengantar Akuntansi 1 dan Implikasinya dalam Pembelajaran, Jurnal Inovasi Pendidikan Ekonomi, Padang: Universitas Negeri Padang, vol. 8 (2), 2018, pp. 122-126.

[6] A. A. Permadi, Pengembangan Media Pembelajaran Interaktif Berbasis Web dengan Pemanfaatan Video 
Conference Mata Pelajaran Produktif Teknik Komputer dan jaringan di Sekolah Menengah Kejuruan, Jurnal Pendidikan Teknologi dan Kejuruan, Makasar: Universitas Negeri Makasar, Oct 2017.

[7] Mulyasa, Pengembangan dan implementasi kurikulum 2013, Bandung: PT. Remaja Rosdakarya, 2016.

[8] N. W. Wardhani, M. Wahono, Keteladanan Guru Sebagai Penguat Proses Pendidikan Karakter, Untirta Civic Education Journal (UCEJ), Indonesia: Sultan Ageng Tirtayasa, vol. 2 (1), 2017.

[9] W. Sanjaya, Strategi Pembelajaran Berorientasi Standar Proses Pendidikan, Jakarta: Kencana, 2009.

[10] A. Fanani, Mengurai Kerancuan Istilah Strategi dan Metode Pembelajaran, Nadwa: Jurnal Pendidikan Islam, Semarang: IAIN Walisongo Semarang, vol. 8 (2), 2014, pp. 171-192.

[11] Y. Siregar, Kompetensi guru dalam bidang strategi perencanaan dan pembelajaran matematika, Formatif: Jurnal Ilmiah Pendidikan MIPA, Jakarta: LPPM Universitas Indraprasta PGRI, vol. 3 (1), 2013, pp. 39-48.

[12] N. Sudjana, Dasar-dasar Proses Belajar Mengajar, Bandung: Sinar Baru Algesindo, 2005.

[13] H. Supriyono, A.N. Saputra, E. Sudarmilah, R. Darsono, Rancang bangun aplikasi pembelajaran hadis untuk perangkat mobile berbasis Android, Jurnal Informatika (JIFO), Yogyakarta: Universitas Ahmad Dahlan, vol. 8 (2), 2014, pp. 907-920.

[14] O. Hamalik, Perencanaan pengajaran berdasarkan pendekatan sistem, Jakarta: PT. Bumi Akasara, 2005

[15] A. Arsyad, Media Pendidikan, Jakarta: PT. Raja Grafindo Persada, 2011.

[16] U. Khasanah, A. A. Istiningrum. Pengaruh Persepsi Siswa Tentang Metode Mengajar Guru Dan Disiplin Belajar Terhadap Prestasi Belajar Akuntansi Siswa Kelas X Program Keahlian Akuntansi SMKN 1 Pengasih Tahun Ajaran 2011/2012 Dengan Motivasi Belajar Sebagai Pemoderasi, Jurnal Pendidikan Akuntansi Indonesia, Yogyakarta: Universitas Negeri Yogyakarta, vol. 10 (2), 2012, pp. 95-113.

[17] I. Suhendra, E. Eny, H. A. Melati, Pengaruh penggunaan media audiovisual powtoon terhadap motivasi dan hasil belajar siswa materi unsur senyawa campuran, Jurnal pendidikan dan pembelajaran, Universitas Yanjungpura, vol. 7 (3), 2018.

[18] I. J. Saputri, D. T. Irafahmi, Sumadi. Media Presentasi Prezi Pada Mata Pelajaran Akuntansi
Untuk Meningkatkan Motivasi Belajar Siswa, Journal of Accounting and Business Education, Universitas Negeri Malang, vol. 2 (4), Sept 2015.

[19] A. Widayati, Metode mengajar sebagai strategi dalam mencapai tujuan belajar mengajar, Jurnal Pendidikan Akuntansi Indonesia, Yogyakarta: Universitas Negeri Yogyakarta, vol. 3 (1), 2004.

[20] M. D. Zeiler, ADADELTA: an adaptive learning rate method. Computer Science, arXiv.org, arXiv:1212.5701v1, Dec 2012

[21] Rahman, Risqi, Samsul Maarif. Pengaruh penggunaan metode discovery terhadap kemampuan analogi matematis siswa SMK Al-Ikhsan Pamarican Kabupaten Ciamis Jawa Barat. Infinity Journal 3 (1), 2014, pp. 33-58.

[22] D. Syah, Perencanaan sistem Pengajaran Pendidikan Agama Islam, Jakarta: Gaung Persada Press, 2007.

[23] A. Asyhari, H. Silvia, Pengembangan Media Pembelajaran Berupa Buletin dalam Bentuk Buku Saku untuk Pembelajran IPA Terpadu, Jurnal Ilmiah Pendidikan Fisika Al-Biruni, Lampung: UIN Raden Intan Lampung, vol. 5 (1), 2016, pp. 1-13

[24] M. Ali, Guru Dalam Proses Belajar Mengajar, Bandung: Sinar Baru Algensindo, 2010.

[25] Musfiqon, Pengembangan Media dan Sumber Media Pembelajaran, Jakarta: PT. Prestas Pustakaraya, 2012.

[26] A. Isman, Instructional Design in Education: New Model, Turkish Online Journal of Educational Technology-TOJET, Turkey: Sakarya University, vol. 10 (1), 2011, pp. 136-142.

[27] AM. Sardiman, Interaksi \& Motivasi Belajar Mengajar, Jakarta: Rajawali Pers, 2011

[28] A. Arsyad, Media Pendidikan, Jakarta: PT. Raja Grafindo Persada, 2011.

[29] T. Nurseto, Membuat media pembelajaran yang menarik, Jurnal Ekonomi dan Pendidikan, Yogayakarta: Universitas Negeri Yogyakarta, vol. 8 (1), 2011

[30] J. Handhika, Efektivitas media pembelajaran IM3 ditinjau dari motivasi belajar, Jurnal Pendidikan IPA Indonesia, Semarang: Universitas Negeri Semarang, vol. 1 (2), 2012, pp. 109-114.

[31] J. R. Lindner, Understanding employee motivation, Journal of extension, USA: Extention Journal Inc, vol. 36 (3), 1998, pp. 1-8.

[32] H.B. Uno, Teori Motivasi dan Pengukurannya, Jakarta: Bumi Aksara, 2008. 